\title{
PROFIL HASIL BELAJAR MATEMATIKA PESERTA DIDIK SEKOLAH
}

\section{DASAR}

\author{
Supriyadi \\ Sekolah Dasar Negeri 3 Kedungwinangun \\ supriyadi110794@gmail.com
}

\begin{abstract}
ABSTRAK
Penelitian ini bertujuan untuk mendeskripsikan profil hasil belajar matematika peserta didik kelas II SD Negeri Kedungwinangun. Penelitian ini merupakan penelitian deskriptif kualitatif. Partisipan penelitian ini yaitu siswa kelas dua di Sekolah Dasar Negeri 3 Kedungwinangun sebanyak 25 peserta didik. Penelitian dikumpulkan dengan observasi, wawancara, dan dokumentasi. Teknik keabsahan data dilakukan dengan triangulasi metode dan sumber. Data dianalisis dengan statistic deskriptif. Hasil penelitian menunjukkan bahwa profil hasil belajar peserta didik pada muatan pelajaran matematika peserta didik sekolah dasar sudah cukup baik dengan persentase $79 \%$ dan dipengaruhi oleh kemampuan guru dalam mengajar, motivasi belajar peserta didik, dan metode pembelajaran yang digunakan guru.
\end{abstract}

Kata Kunci: Hasil belajar, matematika, sekolah dasar

\section{PENDAHULUAN}

Perkembangan teknologi dan ilmu pengetahuan telah memudahkan manusia untuk mendapat informasi dengan mudah dan cepat. Informasi tersebut bersumber dari beberapa tempat di seluruh belahan dunia. Dalam rangka mempelajari informasi ini, maka perlu sumber daya yang mampu mengelola segala kompetensi yang dimiliki olehnya. Kemampuan yang perlu dimiliki yaitu kemampuan kritis, logis, sistematis, dan kreatif. Pola berpikir seperti itu dapat dikembangkan dengan menerapkan pembelajaran matematika. Matematika dianggap memiliki struktur yang kuat da berkaitan erat antar konsepnya. Pembelajaran matematika di sekolah dasar bertujuan untuk memahami, menjelaskan, dan mengaplikasikan konsep matematika secara tepat terutama dalam 
pemecahaman masalah. Selain itu, Departemen Pendidikan Nasional menjelaskan bahwa pembelajaran matematika juga bertujuan untuk menggunakan seluruh penalaran pada sifat dan pola matematika, memecahkan masalah matematika, mengkomunikasikan ide dengan symbol, diagram, atau media lain, serta memunculkan sikap menghargai manfaat matematika dalam keseharian hidup manusia. ${ }^{1}$

Mengingat pentingnya pembelajaran matematika di sekolah dasar, maka perlu perhatian yang khusus untuk mencari solusi peningkatan hasil belajar matematika. Keberhasilan belajar peserta didik pada pembelajaran matematika tentu tidak terlepas dari kualitas pembelajaran dalam mengajar. Menurut Sudjana, kualitas pembelajaran memiliki hubungan yang berbanding lurus dengan hasil belajar. ${ }^{2}$ Semakin baik kualitas pembelajaran, maka semakin baik pula hasil belajar peserta didik. Kualitas pembelajaran tersebut maksudnya ialah efektif atau tidaknya proses pembelajaran. Proses pembelajaran dianggap efektif jika peserta didik terlibat aktif untuk menemukan, membangun, dan mengembangkan pengetahuannya sendiri.

Temuan yang diperoleh oleh Sukrorini menyajikan fakta yang mengejutkan. Hasil belajar matematika peserta didik sekolah dasar masih rendah utamanya pada materi pokok pecahan. ${ }^{3}$ Rata-rata nilai yang diperoleh peserta didik masih di bawah Kriteria Ketuntasan Minimum (KKM). Setelah dianalisis mendalam, ternyata penyebab rendahnya hasil belajr dikarenakan kurang mampunya peserta didik untuk memecahkan masalah dan aktivitas peserta didik di dalam kelas sangat terbatas. Peserta didik sering duduk diam di tengah pembelajaran hanya dengan memperhatikan penjelasan guru saja. Peserta didik menjadi orang yang bergantung pada guru dan kurang terlatih untuk menggunakan alternative lain untuk menyelesaikan masalah matematika. Kesalahan lain yang sering terjadi oleh peserta didik ialah paradigm pembelajaran yang dipraktikan guru di kelas hanya memberikan kesempatan yang sedikit kepada peserta didik untuk meningkatkan ide-ide kreatif dan menemukan solusi pemecahan masalah.

Masalah tersebut memerlukan solusi untuk memecahkan masalah. Maka, perlulah mengkaji gambaran hasil belajar peserta didik di sekolah dasar. Menurut Mudjiono \& Dimyati, hasil belajar diartikan sebagai hasil yang dicapai dalam bentuk skor atau angkat

\footnotetext{
1 Departemen Pendidikan Nasional, Kurikulum Tingkat Satuan Pendidikan, (Jakarta: Departemen Pendidikan Nasional, 2011). 2011)

${ }^{2}$ Nana Sudjana, Penilaian Hasil Proses Belajar Mengajar, (Bandung: Remaja Rosdakarya,

${ }^{3}$ Wiwit Sukrorini, "Peningkatan hasil belajar matematika dengan menggunakan model direct instruction", Jurnal Pendidikan Matematika dan IPA, Vol. 5, No. 1, 2014, hlm. 27-36.
} 
setelah subjek diberikan tes hasil belajar oleh guru. ${ }^{4}$ Sementara itu, Sudjana menjelaskan bahwa hasil belajar merupakan kemampuan peserta didik setelah ia menerima pembelajaran. ${ }^{5}$ Hasil belajar dapat dipengaruhi oleh dua factor yaitu, factor internal (dalam) dan factor eksternal (luar). ${ }^{6}$ Factor dari dalam berasal dari diri peserta didik itu sendiri, sedangkan factor luar berasalh dari lingkungan atau instrumental (kurikulum, guru, dan lain-lain). Supratiknya menjelaskan bahwa hasil belaajr menjadi objek dalam penilaian kelas yang berupa kemampuan peserta didik. ${ }^{7}$ Mereka mendapat nilai setelah mereka mengikuti serangkaian proses pembelajaran matematika ataupun muatan pelajaran lainnya. Dalam taksonomi bloom, penilaian hasil belajar secara garis besar terdiri atas aspek kogntif, afektif, dan psikomotor.

Berdasarkan paparan di atas, maka penelitian ini hendak mendeskripsikan profil hasil belajar matematika peserta didik kelas II SD Negeri Kedungwinangung. Oleh karena itu, rumusan masalah penelitian ini yaitu bagaimana profil hasil belajar matematika peserta didik kelas II SD Negeri Kedungwinangung?

\section{METODOLOGI PENELITIAN}

Penelitian ini menggunakan penelitian kualitatif deskriptif. Penelitian ini bertujuan untuk mendeskripsikan profil hasil belajar matematika peserta didik. Partisipan penelitian ini yaitu siswa kelas dua di SD Negeri 3 Kedungwinangun, Klirong, Kebumen. Adapun jumlah partisipan sebanyak 25 peserta didik. Data dikumpulkan melalui observasi, dokumentasi, dan wawancara. Validitas data dilakukan dengan teknik triangulasi. Jenis triangulasi tersebut terbagi dua yaitu triangulasi metode dan sumber. Sementara itu, hasil penelitian dianalisis dengan metode analisis deskriptif. Metode ini digunakan untuk memperoleh gambaran hasil belajar matematika peserta didik menggunakan acuan analisis deskriptif dan acuan kategori tingkat penguasaan sesuai dengan teori Arifin. Teori tersebut sebagai berikut:

\footnotetext{
${ }^{4}$ Mudjiono \& Dimyati, Belajar dan Pembelajaran, (Jakarta: Rineka Cipta, 2014).

${ }^{5}$ Nana Sudjana, Dasar-dasar Proses Belajar Mengajar, (Bandung: Sinar Baru algensindo, 2000).

${ }^{6}$ Syaiful Bahri Djamarah, Psikologi Belajar, (Jakarta: Rineka Cipta, 2002).

7 Ahmad Supratiknya, Penilaian hasil belajar dengan teknik nontes, (Yogyakarta: Universitas Sanata Dharma, 2012).
} 
Tabel 1. Pengaktegorian Tingkat Penguasaan Standar

\begin{tabular}{|c|c|}
\hline Tingkat Penguasaan (\%) & Skor Standar \\
\hline $90-100$ & A \\
\hline $80-89$ & B \\
\hline $70-79$ & C \\
\hline-69 & D \\
\hline$>59$ & E \\
\hline
\end{tabular}

Keterangan:

$\mathrm{A}=$ Sangat Baik

$\mathrm{B}=$ Baik

$\mathrm{C}=$ Cukup

$\mathrm{D}=$ Kurang

$\mathrm{E}=$ Sangat Kurang

\section{HASIL DAN PEMBAHASAN}

Data penelitian mengenai gambaran hasil belajar matematika peserta didik diperoleh dari dokumen penilaian guru. Data tersebut ditabulasi dan dianalisis menggunakan statistic deskriptif. Dengan begitu, akan menghasilkan data berikut:

Tabel 2. Tabulasi Data Hasil Belajar

\begin{tabular}{|c|c|}
\hline Interval Nilai & Frekuensi \\
\hline $51-55$ & 3 \\
\hline $56-60$ & 1 \\
\hline $61-65$ & 0 \\
\hline $66-70$ & 1 \\
\hline $71-75$ & 5 \\
\hline $76-80$ & 5 \\
\hline $81-85$ & 1 \\
\hline $86-90$ & 1 \\
\hline $91-95$ & 5 \\
\hline $96-100$ & 3 \\
\hline
\end{tabular}

Mempertimbangkan KKM matematika yang ditetapkan oleh sekolah sebesar 70, maka terdapat 21 peserta didik yang mencapai KKM. Sisanya hanya ada empat peserta didik saja yang masih di bawah KKM. Data tersebut memperlihatkan bahwa hasil belajar matematika peserta didik sudah terpenuhi. Gambaran rata-rata hasil belajar matematika 
Tabel 3. Hasil Analisis Skor Hasil Belajar Matematika

\begin{tabular}{|c|c|}
\hline Uraian & Nilai \\
\hline Skor Tertinggi & 100 \\
\hline Skor Terendah & 52 \\
\hline Rata-rata & 79 \\
\hline
\end{tabular}

peserta didik dan sebaran datanya kemudian dianalisis melalui statistic deskriptif. Hasilnya sebagai berikut.

Tabel 4. Kategori Hasil Belajar

\begin{tabular}{|c|c|c|c|}
\hline Tingkat Penguasaan (\%) & Skor Siswa & Kategori & Frekuensi \\
\hline $90-100$ & $90-100$ & A & 8 \\
\hline $80-89$ & $80-89$ & B & 4 \\
\hline $70-79$ & $70-79$ & C & 9 \\
\hline $60-69$ & $60-69$ & D & 1 \\
\hline$>59$ & $50-59$ & E & 3 \\
\hline
\end{tabular}

Data pada Tabel 3 menunjukkan temuan bahwa nilai rata-rata hasil belajar matematika peserta didik yaitu 79. Skor tertinggi peserta didik yaitu 100, sedangkan skor terendah sebesar 52. Kemudian, untuk mengetahui tingkat penguasaan peserta didik terhadap hasil belajar matematika menggunakan acuan tingkat pengkategrian hasil belajar standar lima. Adapun hasilnya sebagai berikut:

Berpijak dari Tabel kategori hasil belajar, maka diperoleh 3 peserta didik termasuk dalam kategori kurang, 1 peserta didik termasuk kategori kurang, 9 peserta didik termasuk kategori cukup, 4 peserta didik termasuk kategori baik, dan 8 peserta didik termasuk kategori sangat baik. Hasil tersebut disebabkan oleh beberapa factor. Beberapa factor tersebut disampaikan oleh narasumber melalui wawancara. Hasil wawancara menunjukkan data bahwa penyebab masih adanya nilai yang kurag maksimal berupa metode pembelajaran konvensional. Metode ini didominasi oleh metode ceramah dan tanya jawab klasikal saja. Temuan ini sejalan dengan temuan Candrawati dimana hasil penelitiannya pada siklus 1 masih memperlihatkan nilai peserta didik yang tidak maksimal. Siswa hanya mencapai nilai 68,64 atau masih ada $56 \%$ peserta didik yang belu tuntas. ${ }^{8}$ Temuan serupa diperoleh oleh Amintoko dimana hasil siklus satu memperlihatkan aktivitas dan keaktifan

${ }^{8}$ Ed. Candrawati, "Penerapan model direct intruction untuk meningkatkan hasil belajar biologi", Jurnal Educatio FKIP UNMA, Vol. 6, No. 1, 2020, hlm. 140-146. 
siswa masih belum maksimal saat pembelajaran. ${ }^{9}$ Aktivitas siswa hanya mencapai $56 \%$, sedangkan keaktifan siswa hanya mencapai 49\%. Hal ini dikarenakan guru masih sering menggunakan model pembelajaran langsung.

Factor lain yang menjadi penyebab masih ada nilai peserta didik yang kurang maksimal yaitu proses pembelajaran yang digunakan selama belajar. Meskipun hanya ada empat peserta didik yang mendapat nilai di bawaj KKM, namun capaian reratanya juga masih standar KKM saja. Studi ini sesuai dengan temuan Rusni et al. yang menunjukkan hasil bahwa pembelajaran masih berpusat pada guru. Keterlibatan peserta didik masih kurang. ${ }^{10}$ Menurut Trianto, keterampilan perlu dikembangkan oleh guru dengan cara mengembangkan pikiran peserta didik, memberikan peluang dan kesempatan kepada peserta didik untuk melakukan penemuan, serta meningkatkan daya ingat peserta didik melalui tanya jawab atau kuis. ${ }^{11}$ Temuan ini senada diungkap oleh Santra menunjukkan bahwa hasil siklus 1 peserta didik masih belum optimal dikarenakan ada peserta didik yang masih perlu remedial atau mengulang. ${ }^{12}$ Hal ini juga dikarenakan peserta didik kurang aktif dalam belajar.

Sementara itu, temuan yang memperlihatkan peserta didik sudah memenuhi nilai KKM juga dipengaruhi oleh beberapa factor. Factor tersebut seperti kemampuan guru mengevaluasi dan memperbaiki pembelajaran. Hasil tersebut diperlihatkan saat observasi. Guru terlihat mengajak peserta didik untuk aktif berpendapat dengan membuat forum diskusi. Seperti yang dikemukakan oleh Iriani bahwa setiap pembelajaran sebaiknya ada fase diskusi, pemberian bimbingan, dan umpan balik. ${ }^{13}$ Tahapan tersebut ada dalam pelaksanaan pembelajaran langsung dimana kegiatan awal yang dilakukan guru yaitu menyiapkan peserta didik dengan membentuk kelompok kecil. Kelompok ini akan menjadi wadah bagi peserta didik untuk diskusi dan menyelesaikan serangkaian kegiatan pembelajaran. Hasil temuan ini juga senada dengan temuan sebelumnya bahwa metode

9 Gunanto Amintoko, "Model pembelajaran direct instruction dalam meningkatkan pemahaman konsep dan hasil belajar definisi limit bagi mahasiswa", Supremum Journal of Mathematics Education (SJME), Vol. 1, No. 1, 2017, hlm. 7-12.

${ }^{10}$ Rusni, Arsyad Bahri, \& Evi Ristiana, "Profil Hasil Belajar IPA Siswa Kelas III SD Inpres Ana Gowa Profile of Science Learning Outcomes of Class III Students of SD Inpres", Prosiding Seminar Nasional Biologi Dan Pembelajarannya, Desember 2017, hlm. 569-574.

11 Trianto, Model Pembelajaran Terpadu: Konsep, Strategi dan Implementasinya dalam kurikulum tingkat satuan pendidikan (KTSP), (Jakarta: Bumi Aksara, 2015).

${ }_{12}$ Wayan Santra, "Implementasi model direct instruction untuk meningkatkan hasil belajar teknik dasar sprint”, Indonesian Journal of Educational Development, Vo. 2, No. 2, 2021, hlm. 382390. https://doi.org/10.5281/zenodo.5257265

${ }_{13}$ Iriani, "Peningkatan Hasil Belajar Matematika Melalui Model Pembelajaran Langsung pada Siswa", Suara Guru: Jurnal Pendidikan Sosial, Sains, Dan Humaniora (SG-JPSSH), Vol. 4, No. 3, 2018, hlm. 797-806. 
diskusi dapat meningkatkan hasil belajar peserta didik pada pembelajaran IPA ${ }^{14}$, meningkatkan hasil pembelajaran Fiqih. ${ }^{15}$

Selain factor guru dengan penggunaan metode diskusinya, factor lain seperti motivasi peserta didik juga tampak menjadi hal yang mempengaruhi maksimalnya nilai yang didapat peserta didik. Sependapat dengan temuan ini, Hamdu \& Agustina menjelaskan bahwa motivasi belajar siswa terbukti dapat meningkatkan prestasi belajar IPA. ${ }^{16}$ Peserta didik mendapat nilai rata-rata 87,46\%. Sejalan dengan itu, Kiswoyowati juga mengungkap bahwa motivasi belajar peserta didik dapat meningkatkan kecakapan hidup peserta didik. ${ }^{17}$ Kecakapan hidup yang diperlihatkan peserta didik seperti mampu berkomunikasi, kerja sama, dan memiliki prestasi yang baik di kelasnya. Lebih lanjut, Warti juga menghasilkan temuan yang sama dengan penelitian ini. Ia menghasilkan temuan bahwa ada pengaruh positif motivasi belajar terhadap hasil belajar peserta didik pada muatan pelajaran matematika. ${ }^{18} \mathrm{Hal}$ ini dikarenakan oleh fakto intelegensi peserta didik (untuk menyesuaikan diri) dan factor motivasi. Temuan ini sesuai dengan teori yang diutarakan oleh Sardiman bahwa motivasi berfungsi sebagai pengoptimal kegiatan pembelajaran, penyemangat, perhatian, dan pengingat peserta didik. ${ }^{19}$

Dari beberapa penjelasan di atas, maka dapat diketahui bahwa profil hasil belajar peserta didik pada muatan pelajaran matematika peserta didik sekolah dasar sudah cukup baik dengan persentasi 79\%. Jumlah ini dipengaruhi oleh kemampuan guru dalam mengajar, motivasi belajar peserta didik, dan metode pembelajaran yang digunakan guru.

\section{KESIMPULAN}

Secara umum, perolehan gambaran hasil belajar matematika peserta didik siswa kelas II SD Negeri Kedungwinangun tergolong cukup baik yang banyak dipengaruhi oleh factor kemampuan guru, motivasi peserta didik, dan metode pembelajaran. Penelitian ini

${ }^{14}$ Netty Ermi, "Penggunaan Metode Diskusi untuk Meningkatkan Hasil Belajar Materi Perubahan Sosial pada Siswa Kelas XII SMA Negeri 4 Pekanbaru", Jurnal SOROT, Vol. 10, No, 2, 2015, hlm. 155-168.

15 Mawardi Ahmad, Syahraini Tambak, Siwal, "Penerapan metode diskusi dalam meningkatkan hasil belajar murid pada pelajaran fiqh", Jurnal Al-Hikmah, Vol. 15, No. 1, 2018, hlm. 60-79.

${ }^{i 6}$ Ghullam Hamdu \& Lisa Agustina, "Pengaruh motivasi belajar siswa terhadap pestasi belajar ipa di sekolah dasar", Jurnal Penelitian Pendidikan, Vol. 12, No. 1, 2011, hlm. 90-96.

${ }_{17}$ Amin Kiswoyowati, "Pengaruh motivasi belajar dan kegiatan belajar siswa terhadap kecakapan hidup siswa", Edisi Khusus, No. 1, 2011, hlm. 120-126.

${ }^{18}$ Elis Warti, "Pengaruh Motivasi Belajar Siswa terhadap Hasil Belajar Matematika Siswa di SD Angkasa 10 Halim Perdana Kusuma Jakarta Timur", Jurnal Pendidikan Matematika STKIP Garut, Vol. 5, No. 2, 2016, hlm. 177-185.

$19 \mathrm{lbid}$. 
memiliki keterbatasan dikarenakan penelitian hanya dilakukan di satu sekolah saja dan hanya pada muatan pelajaran matematika. Oleh sebab itu, peneliti selanjutnya dapat menguji suatu model/metode (seperti metode diskusi) terhadap hasil belajar matematika. Peneliti mendatang juga dapat menganalisis profil hasil belajar peserta didik pada muatan pelajaran IPA, IPS, atau Bahasa Indonesia di sekolah dasar, sekolah menengah pertama, atapun sekolah menengah atas/kejuruan.

\section{DAFTAR PUSTAKA}

Ahmad, M., Tambak, S., \& Siwal. (2018). Penerapan metode diskusi dalam meningkatkan hasil belajar murid pada pelajaran fiqh. Jurnal Al-Hikmah, 15(1), 60-79.

Amintoko, G. (2017). Model pembelajaran direct instruction dalam meningkatkan pemahaman konsep dan hasil belajar definisi limit bagi mahasiswa. Supremum Journal of Mathematics Education (SJME), 1(1), 7-12.

Candrawati, E. (2020). Penerapan model direct intruction untuk meningkatkan hasil belajar biologi. Jurnal Educatio FKIP UNMA, 6(1), 140-146.

Departemen Pendidikan Nasional. (2011). Kurikulum Tingkat Satuan Pendidikan. Departemen Pendidikan Nasional.

Djamarah, S. B. (2002). Psikologi Belajar. Rineka Cipta.

Ermi, N. (2015). Penggunaan Metode Diskusi untuk Meningkatkan Hasil Belajar Materi Perubahan Sosial pada Siswa Kelas XII SMA Negeri 4 Pekanbaru. Jurnal SOROT, 10(2), 155-168.

Hamdu, G., \& Agustina, L. (2011). Pengaruh motivasi belajar siswa terhadap pestasi belajar ipa di sekolah dasar. Jurnal Penelitian Pendidikan, 12(1), 90-96.

Iriani. (2018). Peningkatan Hasil Belajar Matematika Melalui Model Pembelajaran Langsung pada Siswa. Suara Guru: Jurnal Pendidikan Sosial, Sains, Dan Humaniora (SG-JPSSH), 4(3), 797-806.

Kiswoyowati, A. (2011). Pengaruh motivasi belajar dan kegiatan belajar siswa terhadap kecakapan hidup siswa. Edisi Khusus, 1, 120-126.

Mudjiono, \& Dimyati. (2009). Belajar dan Pembelajaran. Rineka Cipta.

Rusni, Bahri, A., \& Ristiana, E. (2017). Profil Hasil Belajar IPA Siswa Kelas III SD Inpres Ana Gowa Profile of Science Learning Outcomes of Class III Students of SD Inpres. Prosiding Seminar Nasional Biologi Dan Pembelajarannya, Desember, 569-574.

Santra, W. (2021). Implementasi model direct instruction untuk meningkatkan hasil belajar 
teknik dasar sprint. Indonesian Journal of Educational Development Volume, 2(2), 382-390. https://doi.org/10.5281/zenodo.5257265

Sudjana, N. (2000). Dasar-dasar Proses Belajar Mengajar. Sinar Baru algensindo.

Sudjana, N. (2001). Penilaian Hasil Proses Belajar Mengajar. Remaja Rosdakarya.

Sukrorini, W. (2014). Peningkatan hasil belajar matematika dengan menggunakan model direct instruction. Jurnal Pendidikan Matematika Dan IPA, 5(1), 27-36.

Supratiknya, A. (2012). Penilaian hasil belajar dengan teknik nontes. Universitas Sanata Dharma.

Trianto. (2015). Model Pembelajaran Terpadu: Konsep, Strategi dan Implementasinya dalam kurikulum tingkat satuan pendidikan (KTSP). Bumi Aksara.

Warti, E. (2016). Pengaruh Motivasi Belajar Siswa terhadap Hasil Belajar Matematika Siswa di SD Angkasa 10 Halim Perdana Kusuma Jakarta Timur. Jurnal Pendidikan Matematika STKIP Garut, 5(2), 177-185. 